\title{
EFFECT OF RICE STRAW AND APPLICATIONS OF POTASSIUM SILICATE, POTASSIUM HUMATE AND SEAWEED EXTRACT ON GROWTH AND SOME MACRONUTRIENTS OF SWEET PEPPER PLANTS UNDER IRRIGATION DEFICIT
}

\author{
Nesma, E.E. Youssif'; H.S.M. Osman²; Y.A.M. Salama' and \\ Sanaa A.M. Zaghlool ${ }^{2}$ \\ 1- Plant Adaption Unit-Genetic Resource Dept., Desert Research Center, Cairo, Egypt. \\ 2- Agric. Botany Dept., Fac. of Agric., Ain Shams Univ., Cairo, Egypt.
}

Keywords: Sweet pepper, Irrigation deficit, Rice straw, Potassium silicate, Potassium humate, Seaweed extract, Growth, N, P, K, Ca

\section{ABSTRACT}

Field experiment was conducted during the two growing seasons of 2013-2014 and 2014-2015, in a private farm at El-Salheya El-Gedida City, Ismailia Governorate, Egypt, to investigate the effect of rice straw (RS) as alternative to sandy soil (SS) and drenching applications of potassium humate $\left(\mathrm{K}_{2}-\mathrm{HA}\right)$ at $2 \mathrm{~g} / \mathrm{l}$, potassium silicate $\left(\mathrm{K}_{2} \mathrm{SiO}_{3}\right)$ at 5 $\mathrm{g} / \mathrm{l}$, and seaweed extract (SWE) at $0.5 \mathrm{~g} / \mathrm{l}$ on improving growth of sweet pepper (capsicum annu$u m$ L.) plants under deficit irrigation every $2\left(\mathrm{I}_{2}\right), 3$ $\left(I_{3}\right)$ and $4\left(I_{4}\right)$ days in addition to daily irrigation $\left(I_{1}\right)$ as control. Plant samples were taken at 90 days after transplanting to record leaf area, shoot fresh and dry weights, in addition to, determination of leaf relative water content (LRWC), concentrations of $\mathrm{N}, \mathrm{P}, \mathrm{K}$ and $\mathrm{Ca}$. Mean values of drenching applications showed significant increase in the growth parameters ;shoot fresh and dry weights, leaf area, LRWC, as well as, concentrations of $\mathrm{N}$, $\mathrm{P}$ and $\mathrm{Ca}$ in the two seasons comparing to untreated control and the best results were due to $\mathrm{K}_{2}$ $\mathrm{HA}$ followed by SWE then $\mathrm{K}_{2} \mathrm{SiO}_{3}$. The highest concentration of $\mathrm{K}$ was obtained by $\mathrm{K}_{2} \mathrm{SiO}_{3}$ followed by $\mathrm{K}_{2}-\mathrm{HA}$ then SWE. Plants were grown on RS showed significant increase in LRWC comparing to plants were grown on SS. Plants were applied with $\mathrm{I}_{2}+\mathrm{K}_{2}-\mathrm{HA}+\mathrm{SS}$ showed the highest significant value of shoot fresh weight, shoot dry weight, leaf area, N, P and Ca concentrations followed by $\mathrm{I}_{2}+\mathrm{SWE}+\mathrm{SScomparing}$ to control plants applied with $\mathrm{I}_{1}+\mathrm{SS}$ without drenching applications. Plants were grown on RS showed significant increase in growth parameters comparing with control plants but less than those were grown on SS. The best results were achieved by $\mathrm{I}_{3}+\mathrm{K}_{2}-\mathrm{HA}+\mathrm{RS}$, $I_{3}+S W E+R S, I_{4}+K_{2}-H A+R S$. Plants were grown on rice strawunderl ${ }_{3}$ irrigation and applied with $\mathrm{K}_{2}$ $\mathrm{HA}$ or SWE showed significant increase in $\mathrm{N}, \mathrm{P}$ and $\mathrm{Ca}$ concentrations, while, under $\mathrm{I}_{4}$ irrigation an increase in $\mathrm{N}$ and $\mathrm{P}$ concentrations was obtained by $\mathrm{K}_{2}-\mathrm{HA}$.The highest concentrations of $k$ were observed with plants grown on SS under the highest level of irrigation deficit $\mathrm{I}_{4}$ by $\mathrm{K}_{2} \mathrm{SiO}_{3}$. It could be concluded from the present study that rice straw could alleviate the negative effect of low water supply and applications of $\mathrm{K}_{2}-\mathrm{HA}$ and SWE are recommended for enhancing sweet pepper growth and nutrient elements uptake under water deficit conditions.

\section{INTRODUCTION}

Sweet pepper (Capsicum annuum L.) is a member of the solanaceous fruity vegetables group. It is one of the most important, popular and favorite vegetable crops cultivated in Egypt for local consumption and exportation (El-Bassiony et al 2010)Sweet pepper is consumed both as fresh and dehydrated spices (Bosland and Vostava, 2000). Pepper is a good source of vitamins A, C, E, B1, and B2, potassium, phosphorus and calcium. Moreover, it is one of the valuable medicinal plants in pharmaceutical industries because of high amounts of antioxidant (Aminifard et al 2012). 
The relative amount of water available to agriculture is declining worldwide due to the rapid population growth and the greater incidence of drought in recent years caused by climate change and different human activities. Competing agricultural, municipal and industrial water usage will eventually threaten food security(UNWWAP, 2003 and Bank, 2006). Continued successful management of the limited amount of water available for agricultural uses depends upon better agronomic practices and enhanced understandings of water productivity, defined as the crop productivity output per unit of water consumed (Howell et al 1998 and Jones, 2004).

Rice straw represents an important summer crop by-product in Egypt. The high amount of rice straw that produced (more than 5 million tons every year from the rice fields), there is no organized practical use for this waste until now, which it causes serious pollution when disposed by burning. The very cheap price and the major components of rice straw are silica, lignin and hemicelluloses, which are not attractive or favorable for soil fungi or nematodes, it could represent a good substrate for sowing instead of natural infested soil under open field conditions(Abdet-Sattar et al 2008). El-Sayed et al (2015) demonstrated that rice straw could be recommended as a growing substrate in replacing naturally infested soil, as it can improve the production of pepper plants under greenhouse conditions in Egypt, with saving 35$38 \%$ of irrigation water.

Silicon is the second most abundant element in the earth's surface and is one of the important elements that form clay minerals structure in soils and is known as a useful element for plants (Epstein, 1999). The amount of silicon uptake and collection by plants is variable between 0.1 to 10 percent of dry weight. Today, silicon is not classified as an essential element for plants but its beneficial effects has been observed in a wide range of plant species (Epstein, 1994 and Ma \& Yamaji, 2006). High silica uptake has been shown to improve drought resistance, increase resistance to fungi and other pathogens, and increase plant growth rate and yield (Marschner, 1995; Piorr, 1986 and Belanger et al 1995). The role of Si has proven to be in response to different abiotic and biotic stress. Meaningfully, increasing resistance to diseases and pathogens, metal toxicities, salinity and drought stresses are some of the most important functions of this element. Indeed, protecting plants against extremely high or low temperature needed for nodule configuration, as well as beneficial effect over the mineral composition and enzyme activities of plants are other advantages (Epstein, 2001).

Karakurt et al (2009) reported that potassium humate $\left(\mathrm{K}_{2}-\mathrm{HA}\right)$ can be used as a non-expensive source for potassium and it could be used as soil dressing, drenching or foliar applications. It was already subjected to many studies in various areas of agriculture. The mechanism of humate material in promoting plant growth is not completely known. It was reported by many researchers that $\mathrm{K}_{2}-\mathrm{HA}$ application increased the plant growth, nutrient uptake and plant yield and quality as well. Also, they reported that $\mathrm{K}_{2}-\mathrm{HA}$ application led to increasing and improving pepper plant growth parameters. Nardi et al (2002) reported that the simulative effect of $\mathrm{K}_{2}-\mathrm{HA}$ in enhancing fruit characteristics may be attributed to that some plant hormone like substances seem to be present in the humic substances.

The role of seaweed extract (SWE) in alleviating the effect of abiotic stress and enhancing plant growth have been mentioned by many workers on cucumber, soybean, fenugreek and wheat (Wang, et al 2005 and Chernane, 2015). The improvement in vegetative growth characters induced by seaweed extracts was attributed to the role of seaweed extracts as bio-stimulants for plant growth and development because of the presence of trace elements, organic substances like amino acids and plant growth regulators such as auxin, cytokinins and gibberellins which improve vegetative growth (Abdel-Maguid et al 2004 and El Moniem \& Abd-Allah, 2008).

Therefore, the present study was conducted to investigate the effect of growing media (compacted rice straw bales as soil alternative), drenching applications of potassium silicate, potassium humate and seaweed extract, on growth and concentration of some macronutrients of sweet pepper plants grown under different levels of irrigation deficit.

\section{MATERIAL AND METHODS}

Field experiment was conducted during the two growing seasons of 2013-2014 and 2014-2015, in a private farm $\left(30^{\circ} 39^{\prime} \mathrm{N}, 32^{\circ} 06^{\prime} \mathrm{E}\right)$ at El-Salheya $\mathrm{El}-$ Gedida City, Ismailia Governorate, Egypt, to investigate the effect of rice straw as soil alternative and drenching applications of potassium silicate $\left(\mathrm{K}_{2} \mathrm{SiO}_{3}\right)$, potassium humate $\left(\mathrm{K}_{2}-\mathrm{HA}\right)$, and seaweed extract (SWE) on improving growth and productivity of sweet pepper under deficit irrigation. 


\section{plants under irrigation deficit}

\section{Preparation of transplants and rice straw bales (soil alternative)}

\subsection{Transplants preparation}

Imported hybrid seeds of sweet pepper plant (capsicum annuum L.), "Masillia" hybrid was purchased from Rijk Zwaan company. Seeds were sown in the shading screen nursery in July $1^{\text {st }}$ during the two growing seasons of 2013-2014 and 2014-2015.

\subsection{Preparing of rice straw bales}

Compacted rice straw bales $(30 \mathrm{~cm}$ height $\times 45$ $\mathrm{cm}$ width $\times 100 \mathrm{~cm}$ length) obtained from commercial supplier, were sterilized in boiling water and then were arranged to form ridge with two rows on each ridge in greenhouse for sweet pepper cultivation. Drip irrigation lines were extended on top of the rice straw bales with two drip lines on each row. The straw bales were first irrigated for six hours for washing out soil particles, then water irrigated daily for three weeks before transplanting to prevent reduction of its volume during growing season.

\subsection{Transplants culture}

Seedlings of sweet pepper which have three or four true leaves (45 days old) were transplanted into the greenhouses at a private farm at ElSalheya El-Gedida City, Ismailia Governorate, Egypt, in August $15^{\text {th }}$ during the two growth seasons in sandy soil and rice straw bales. The physical and chemical analysis of soil and water are presented in Table 1 (A \& B). The seedlings were transplanted on two side of ridge at $40 \mathrm{~cm}$ apart, the distances between seedling were $40 \mathrm{~cm}$ apart in both of rice straw bales and sandy soil. The plants were watered by the drip irrigation system until the end of the season.

Table 1.A. Chemical analysis of soil and water

\begin{tabular}{|c|c|c|c|c|c|c|c|c|c|c|}
\hline & $\mathbf{p H}$ & $\mathbf{E C}$ & $\mathbf{T D S}$ & $\mathbf{C a}^{++}$ & $\mathbf{M g}^{++}$ & $\mathbf{N a}^{+}$ & $\mathbf{K}^{+}$ & $\mathbf{C l}^{-}$ & $\mathbf{H C O}_{3}{ }^{-}$ & $\mathbf{S O}_{4}^{-{ }^{-}}$ \\
\hline Soil & 7.5 & 4.080 & 2659 & 16.15 & 9.54 & 11.31 & 3.06 & 11.36 & 1.20 & 29.12 \\
& & $\mathrm{ds} / \mathrm{m}$ & $\mathrm{mg} / \mathrm{l}$ & $\mathrm{meq} / \mathrm{l}$ & $\mathrm{meq} / \mathrm{l}$ & $\mathrm{meq} / \mathrm{l}$ & $\mathrm{meq} / \mathrm{l}$ & $\mathrm{meq} / \mathrm{l}$ & $\begin{array}{c}\mathrm{meq} / \mathrm{l} \\
\mathrm{meq} / \mathrm{l}\end{array}$ \\
\hline Water & \multirow{2}{*}{8.6} & 1410 & 697 & 1.34 & 0.77 & 8.91 & 0.51 & 5.68 & 2.69 & 2.90 \\
& & $\mu \mathrm{s} / \mathrm{cm}$ & $\mathrm{mg} / \mathrm{l}$ & $\mathrm{mg} / \mathrm{l}$ & $\mathrm{mg} / \mathrm{l}$ & $\mathrm{mg} / \mathrm{l}$ & $\mathrm{mg} / \mathrm{l}$ & $\mathrm{mg} / \mathrm{l}$ & $\mathrm{mg} / \mathrm{l}$ & $\mathrm{mg} / \mathrm{l}$ \\
\hline
\end{tabular}

Table 2.B. Physical properties of the experimental site soil

\begin{tabular}{|c|c|c|c|c|c|c|}
\hline \multicolumn{6}{|c|}{ Particles size distribution (\%) } & \multirow{2}{*}{$\begin{array}{c}\text { Texture } \\
\text { class } \\
\end{array}$} \\
\hline $\begin{array}{l}\text { Very coarse } \\
\text { sand }\end{array}$ & Coarse sand & $\begin{array}{l}\text { Medium } \\
\text { sand }\end{array}$ & Fine sand & Very fine sand & Silt \& Clay & \\
\hline $2-1 \mathrm{~mm}$ & $1-0.50 \mathrm{~mm}$ & $\begin{array}{c}0.50-0.25 \\
\mathrm{~mm}\end{array}$ & $\begin{array}{c}0.25-0.125 \\
\mathrm{~mm}\end{array}$ & $\begin{array}{c}0.125-0.064 \\
\mathrm{~mm}\end{array}$ & $<0.064 \mathrm{~mm}$ & \\
\hline 2.25 & 41.65 & 33.42 & 16.08 & 5.75 & 0.85 & Sand \\
\hline
\end{tabular}

\section{Experimental design and agricultural prac- tices}

\subsection{Experimental design and tested factors}

a) Deficit irrigation treatments were applied in 3 deficit levels (every 2, 3 and 4 days) in addition to daily irrigation as control. The irrigation applications started after 15 days from transplanting.

b) To maximize growth of sweet paper plants under deficit irrigation, application of potassium humate $\left(\mathrm{K}_{2}-\mathrm{HA}\right)$ at $2 \mathrm{~g} / \mathrm{l}$, potassium silicate $\left(\mathrm{K}_{2} \mathrm{SiO}_{3}\right)$ at $5 \mathrm{~g} / \mathrm{l}$, and seaweed extract (SWE) at $0.5 \mathrm{~g} / \mathrm{l}$ in addition to tap water as control were used as soil drenching applications. Drenching applications 
were applied with 10-day intervals started after 15 days from transplanting. Potassium humate with the commercial name "Humic Total" (Technogreen Co. Egypt, and LEILI Agrochemistry Beijing, China) has the following properties (humic acid $80 \%-\mathrm{K}_{2} \mathrm{O}$ $12 \%$ - water solubility: $98 \%$ soluble $-\mathrm{pH}: 8-9-$ bulk density: $83 \mathrm{~g} / 100 \mathrm{ml})$. whereas, seaweed extract with the commercial name "Algaa 600" (Technogreen Co. Egypt, and LEILI Agrochemistry Beijing, China) has the following properties (organic matter $55 \%$ - alginic acid $10 \%$ - total nitrogen $0.6 \%$-phosphorus $\left(\mathrm{P}_{2} \mathrm{O}_{5}\right) 5 \%$ - potassium $\left(\mathrm{K}_{2} \mathrm{O}\right)$ $20 \%-\mathrm{Mg} \mathrm{0.06 \%}$ - Ca 1.6\% - Fe 0.3\% - Cu 45ppm - S $1.5 \%$ water solubility: $100 \%$ soluble $-\mathrm{pH}$ : 9 10).

c) Two types of growing media were used for this investigation; rice straw and sandy soil (control).

The experimental layout was split-split plot design with three replicates. Irrigation treatments were applied in the main plots, soil drenching applications were applied in the sub plots and the growing media were applied in the sub-sub plots. Total number of treatments is 32 (2 types of growing media $\times 4$ drenching application $\times 4$ irrigation levels). The experimental unit area (plot area) was $12 \mathrm{~m}^{2}$.

\subsection{Agricultural practices}

Agricultural management, fertilization, disease and pest control programs were performed as recommended by the Egyptian Ministry of Agriculture and Land reclamation. The fertilization depended on the physiological status of sweet pepper plants during different stages of development.

\section{Vegetative growth measurements}

Plant samples were taken at random from each experimental plot at 90 days after transplanting (DAT), to record leaf area, shoot system fresh and dry weight.

- Leaf area $\left(\mathrm{cm}^{2}\right)$ was determined using leaf area meter machine model ADC Bioscientific Ltd., Japan. Samples were taken from fully expanded leaves (leaf number 4 from the top).

- Fresh weight $(\mathrm{g})$ of shoot system (stem and leaves) was determined in g/plant.

- Dry weights of shoot system samples were placed in paper bags and dried in oven $\left(70^{\circ} \mathrm{C}\right)$ until a constant dry weight was reached (A.O.A.C., 2005).

\section{Plant water status measurement}

\section{Determination of leaf relative water content (LRWC)}

Leaf relative water content was determined according to the method of (Schonfeld et al 1988) in the full expanded fourth leaf from the top of the plant. Twenty leaf discs samples $(10 \mathrm{~mm}$ in diameter) were taken with a cork borer from three plants per replicate and placed in a reweighed Petri dish to determine fresh weight (f.w), then discs were floated for 24 hours in distilled water inside a closed Petri dish until the discs became fully turgid. Discs samples were weighed periodically, after gently wiping the water from the leaf surface with a filter paper to determine turgid weight (t.w). Finally, the leaf discs were placed in a pre- heated oven at $80 \circ \mathrm{C}$ to a constant weight (almost $12 \mathrm{~h}$ ) and weighed again to obtain dry weight (d.w). LRWC \% was calculated using the values of (f.w), (t.w) and (d.w) according to the equation as follow:

$$
L R W C \%=\frac{f . w-d . w}{t . w-d . w} \times 100
$$

\section{Determination of minerals concentration}

Samples of dried leaves $(0.2 \mathrm{~g})$ were wet digested in a mixture of $\mathrm{H}_{2} \mathrm{SO}_{4}: \mathrm{H}_{2} \mathrm{O}_{2}$ for chemical analysis of minerals $\mathrm{P}, \mathrm{K}$, and $\mathrm{Ca}$ (A.O.A.C., 2005).

\subsection{Nitrogen}

Total nitrogen concentration was determined using the micro-Kjeldahl method as described by Horneck and Miller (1998).

\subsection{Phosphorus}

Phosphorus concentration was determined using molybdovanadophosphoric acid colorimetric method according to (Jackson, 1973).

\subsection{Potassium}

The diluted digested sample $(1+9(\mathrm{v} / \mathrm{v})$ with water) is nebulized into an air-propane flame, where it is vaporized; potassium compounds are atomized and the potassium atoms thus formed emit radiation of which the intensity is measured at a wavelength of $766.5 \mathrm{~nm}$ using flame emission spectrometer (A.O.A.C., 2005).. 

plants under irrigation deficit

\subsection{Calcium}

The diluted digested sample $(1+9(\mathrm{v} / \mathrm{v})$ with water) is vaporized in an air-acetylene flame; calcium compounds are atomized and the $\mathrm{CaOH}$ molecules thus formed emit radiation of which the intensity is measured at a wavelength of $622 \mathrm{~nm}$ using flame emission spectrometer (A.O.A.C., 2005).

\section{Statistical Analysis}

Data of the two seasons were statistically analyzed using CoStat software (version 6.4, CoHort Software, USA) according to the method described by (Gomez and Gomez (1984). Split-split plot analysis of variance (ANOVA) were used to test for significant differences among irrigation intervals, soil applications, types of cultivation media and their interactions at $P<0.05$, followed by Tukey's HSD test.

\section{RESULTS AND DISCUSSION}

\section{Growth parameters}

Data presented in Tables $(2$ - 4) reveal the effect of growing media (sandy soil and compacted rice straw bales) and drenching applications of potassium humate $\left(\mathrm{K}_{2}-\mathrm{HA}\right)$, potassium silicate $\left(\mathrm{K}_{2} \mathrm{SiO}_{3}\right)$ and seaweed extract (SWE) on some growth parameters of sweet pepper plants grown under deficit irrigation; every $2\left(I_{2}\right), 3\left(I_{3}\right)$ and $4\left(I_{4}\right)$ days in addition to daily irrigation $\left(\mathrm{I}_{1}\right)$ as control.

Mean values of irrigation treatments demonstrate significant increase in shoot fresh weight by $I_{2}$ followed by $I_{3}$ then $I_{4}$ compared to $I_{1}$ in the two seasons of 2013/2014and 2014/2015. Significant increase in shoot dry weight was obtained by $I_{3}$ followed by $I_{2}$ then $I_{4}$ comparing to $I_{1}$, but there were no significant differences between $I_{4}$ and $I_{1}$ in the first season. An increase in leaf area was obtained by $I_{3}$ followed by $I_{2}$ then $I_{4}$ comparing to $I_{1}$, but there were no significant differences between $I_{2} \& I_{3}$ and $I_{1} \& I_{4}$ in the first season.

These results are in agreement with Ezzo et al (2010), they revealed that moderate and medium irrigation regimes were able to compete high irrigation levels regarding sweet pepper vegetative growth traits; total fresh and dry weights.

Mean values of drenching applications show significant increase in the growth parameters; shoot fresh and dry weights, and leaf area by all applications in the two seasons comparing to untreated control and the best results were due to $\mathrm{K}_{2}$ $\mathrm{HA}$ followed by SWE then $\mathrm{K}_{2} \mathrm{SiO}_{3}$.
These results confirm with the findings of Abou El-Nasr \& Ibrahim (2011) and Awwad (2015) who mentioned that application of $\mathrm{K}_{2}-\mathrm{HA}$ markedly increased vegetative growth of carrot and maize plants respectively. Refaiy et al (2016) revealed that $\mathrm{K}_{2}-\mathrm{HA}$ significantly increased vegetative growth of Grandnaine banana plantlets. Zhang and Schmidt (1997) stated that seaweed products exhibit growth-stimulating activities. Kowalski et al (1999) described the positive impact of SWE on potato plant growth since they significantly affected shoot growth. Several workers proved that SWE contain a variety of plant hormones including cytokinins, auxins, gibberellic acid and salicylic acid determined indirectly by bioassays reviewed by (Khan et al 2009 and Craigie, 2011). Silicon application on Tagetuspatula L. significantly increased fresh and dry weights of plants (Sivanesan et al 2010). Also, Si application to sorghum led to increase in leaf area index, specific leaf weight, chlorophyll content, root and leaf dry weights (Ahmed et al 2011).

Plants were grown on rice straw (RS) showed significant reduction in growth parameter values comparing to sandy soil (SS). These results are not consistent with the results of Abdet-Sattar et al (2008) and El-Sayed et al (2015), they stated that using rice straw as growing medium increased vegetative growth of strawberry and sweet pepper comparing with using natural soil or sandy soil respectively. However, it was tended in the present study to apply the same fertilization program to rice straw and sandy soil, while, Abdet-Sattar et al (2008) for instance used extra fertilization during preparing rice straw bales and this may explain the positive effect of rice straw on growth, whereas, they applied dissolved ammonium and potassium sulphate and phosphoric acid $85 \%$ fertilizers daily through the irrigation system, 10-12 days before planting, for rice straw fermentation.

Concerning interaction between treatments, plants irrigated every 2 days, grown on sandy soil and drenched with $\mathrm{K}_{2}-\mathrm{HA}\left(\mathrm{I}_{2}+\mathrm{K}_{2}-\mathrm{HA}+\mathrm{SS}\right)$ showed the highest significant values of shoot fresh weight (493.00, 494.67g), shoot dry weight (49.67, $50.67 \mathrm{~g})$ and leaf area $\left(121.94,123.15 \mathrm{~cm}^{2}\right) \mathrm{com}-$ paring to control plants applied with $\mathrm{I}_{1}+$ Control + SS which recoded shoot fresh weight (199.67, $201.33 \mathrm{~g})$, shoot dry weight $(40.67,42.00 \mathrm{~g})$ and leaf area $\left(90.76,91.98 \mathrm{~cm}^{2}\right)$ in the two seasons respectively. Marked increase in growth parameters was also recorded by $\mathrm{I}_{2}+\mathrm{SWE}+\mathrm{SS}, \mathrm{I}_{1}+\mathrm{K}_{2}$ $\mathrm{HA}+\mathrm{SS}, \mathrm{I}_{2}+\mathrm{K}_{2} \mathrm{SiO}_{3}+\mathrm{SS}, \mathrm{I}_{1}+\mathrm{SWE}+\mathrm{SS}$ and $\mathrm{I}_{3}+$ $\mathrm{K}_{2}-\mathrm{HA}+\mathrm{SS}$. 

plants under irrigation deficit 

plants under irrigation deficit

Meanwhile, plants were grown on RS showed significant increase in growth parameters but less than those were grown on SS. The best results of shoot fresh weight were achieved by $\mathrm{I}_{3}+\mathrm{K}_{2}-\mathrm{HA}+$ RS $(376.00,414.00 \mathrm{~g})$ followed by $\mathrm{I}_{3}+\mathrm{SWE}+\mathrm{RS}$ $(365.33,383.00 \mathrm{~g})$ or $\mathrm{I}_{4}+\mathrm{K}_{2}-\mathrm{HA}+\mathrm{RS}$ (347.33, $399.00 \mathrm{~g}$ ) in the two seasons respectively comparing to plants applied with $I_{1}+$ Control + SS (199.67, $201.33 \mathrm{~g}$ ).

The previous results elucidate the stimulating effect of $\mathrm{K}_{2}-\mathrm{HA}$ on growth parameters of plants were grown on $S S$ under irrigation $I_{2} \& I_{3}$. Meanwhile, $\mathrm{SWE}$ and $\mathrm{K}_{2} \mathrm{SiO}_{3}$ enhanced growth of plants grown on SS under irrigation $\mathrm{I}_{2}$.

The role of $\mathrm{K}_{2}-\mathrm{HA}$ as bio-stimulant in stimulating plant growth and reducing the effect of abiotic stress has been established by Rafat et al (2012) and Awwad (2015) on Zea. mays L. under water deficiency stress and by Refaiy et al (2016) on

Grandnaine banana plantlets under salt stress. The role of seaweed extract on improving growth under drought stress has been mentioned by Spann and Little (2011) on orange trees and by Xu and Leskovar (2015) on fresh and dry weights of spinach (Spinacia oleracea L.) plants.

Liu et al (2009) mentioned that silicon additions increased forage biomass (increased shoot development and plant height) under moderate water stress and increased shoot development of alfalfa (Medicago sativa) under light water stress.

Potassium humate and SWE stimulated growth parameters of plants grown on RS under higher levels of water deficit $I_{3} \& I_{4}$. These results obviously demonstrate the positive effect of RS on keeping water under water deficiency condition. El-Sayed et al (2015) demonstrated that rice straw as a growing substrate can improve the production of pepper plants under greenhouse conditions with saving $35-38 \%$ of irrigation water.

\section{Leaf relative water content}

Mean values of irrigation, data in Table (5) show that the highest values of leaf relative water content (LRWC) were recorded by $I_{3}$ followed by $I_{4}$ then $\mathrm{I}_{2}$ and $\mathrm{I}_{1}$.

Drenching applications showed significant increase in LRWC values by all applications in the two seasons comparing to untreated control and the best results were due to $\mathrm{K}_{2}-\mathrm{HA}$ followed by SWE then $\mathrm{K}_{2} \mathrm{SiO}_{3}$.

Plants were grown on RS showed significant increase in leaf relative water content (LRWC); $74.72,76.00 \%$ comparing to plants were grown on
SS; $58.88,60.14 \%$ in the two seasons respectively.

Application of $\mathrm{I}_{3}+\mathrm{K}_{2}-\mathrm{HA}+\mathrm{RS}$ resulted in the highest significant values of LRWC (89.80, 91.36 $91.36 \%$ ) while plants were grown on SS and received the same treatments $\mathrm{I}_{3}+\mathrm{K}_{2}-\mathrm{HA}+\mathrm{SS}$ recoded $(61.75,63.82 \%)$ in the two seasons respectively. However, plants were grown on RS surpassed plants grown on SS in LRWC. High values of LRWC were recorded by $\mathrm{I}_{3}+\mathrm{SWE}+\mathrm{RS}$ (82.54, $84.26 \%)$ and $\mathrm{I}_{4}+\mathrm{K}_{2}-\mathrm{HA}+\mathrm{RS}(89.13,90.84 \%)$ comparing to $\mathrm{I}_{1}+$ Control $+\mathrm{SS}(56.77,58.37 \%)$.

The superiority of rice over LRWC confirm the finding of El-Sayed et al (2015) that straw culture may be recommended for the sweet pepper production and reducing water consumption under greenhouse conditions. The increase of LRWC in plants grown on RS under $I_{3} \& I_{4}$ and were applied with $\mathrm{K}_{2}-\mathrm{HA}$ is referred to the impact of $\mathrm{K}_{2}-\mathrm{HA}$ on alleviating water stress influences as mentioned by Rafat et al (2012) and Awwad (2015).

\section{Nutrient elements}

Tabulated data in Tables (6-9) show the effect of deficit irrigation, drenching applications, growing media and their interactions on some macronutrients; N, P, K and Ca. Plants were grown on SS showed significant increase in $\mathrm{N}, \mathrm{K}$ and $\mathrm{P}$ concentrations. Meanwhile, there was no significant differences in $\mathrm{Ca}$ concentrations between both growing media.

Application of $\mathrm{K}_{2}-\mathrm{HA}$ gave the highest concentrations of $\mathrm{N}, \mathrm{P}$ and $\mathrm{Ca}$ followed by SWE then $\mathrm{K}_{2} \mathrm{SiO}_{3}$. The highest concentration of $\mathrm{K}$ was obtained by $\mathrm{K}_{2} \mathrm{SiO}_{3}$ followed by $\mathrm{K}_{2}-\mathrm{HA}$ then SWE.

Data in Table (6) show that $\mathrm{I}_{2}+\mathrm{K}_{2}-\mathrm{HA}+\mathrm{SS}$ gave the highest significant values of $\mathrm{N}$ concentration followed by $\mathrm{I}_{2}+\mathrm{SWE}+\mathrm{SS}$ then $\mathrm{I}_{2}+\mathrm{K}_{2} \mathrm{SiO}_{3}+\mathrm{SS}$ and $\mathrm{I}_{1}+\mathrm{K}_{2}-\mathrm{HA}+\mathrm{SS}$ in both seasons. Significant increases of $\mathrm{N}$ concentration were also obtained by $\mathrm{I}_{3}+\mathrm{K}_{2}-\mathrm{HA}+\mathrm{RS}, \mathrm{I}_{3}+\mathrm{SWE}+\mathrm{RS}$ and $\mathrm{I}_{4}+\mathrm{K}_{2}-\mathrm{HA}+$ $\mathrm{RS}$ in the two seasons comparing with control plants $\mathrm{I}_{1}+$ Control $+\mathrm{SS}$.

Data in Table (7) reveal that the highest significant values of $P$ concentration were obtained by $\mathrm{I}_{2}+\mathrm{K}_{2}-\mathrm{HA}+\mathrm{SS}$ followed by $\mathrm{I}_{2}+\mathrm{SWE}+\mathrm{SS}$ and $\mathrm{I}_{1}+\mathrm{K}_{2}-$ $\mathrm{HA}+\mathrm{SS}$ thenl $\mathrm{I}_{3}+\mathrm{K}_{2}-\mathrm{HA}+\mathrm{RS}$. There were no significant differences between $\mathrm{I}_{3}+\mathrm{K}_{2}-\mathrm{HA}+\mathrm{RS}$ and $\mathrm{I}_{2}+$ $\mathrm{SWE}+\mathrm{SS}$ in both seasons. Application of $\mathrm{I}_{3}+\mathrm{SWE}$ (or $\left.\mathrm{K}_{2} \mathrm{SiO}_{3}\right)+\mathrm{RS}$ and $\mathrm{I}_{4}+\mathrm{K}_{2}-\mathrm{HA}+\mathrm{RS}$ showed significant increase in $\mathrm{P}$ concentrations comparing with control plants $I_{1}+$ Control + SS . 
Nesma Youssif; Osman; Salama and Sanaa Zaghlool 

plants under irrigation deficit 

plants under irrigation deficit 

plants under irrigation deficit

The highest values of $\mathrm{K}$ concentration (Table 8) in the two seasons were obtained by $\mathrm{I}_{4}+$ $\mathrm{K}_{2} \mathrm{SiO}_{3}+\mathrm{SS}$ followed by $\mathrm{I}_{4}+\mathrm{SWE}+\mathrm{SS}$ then $\mathrm{I}_{4}+\mathrm{K}_{2}-$ $\mathrm{HA}+\mathrm{SS}$. Plants were grown on RS underl $\mathrm{I}_{2} \mathrm{I}_{3}$ or $\mathrm{I}_{4}$ in combination with $\mathrm{K}_{2} \mathrm{SiO}_{3}$ gave significant increase in $\mathrm{K}$ concentrations comparing with control plants $\mathrm{I}_{1}+$ Control $+\mathrm{SS}$.

The highest values of $\mathrm{Ca}$ concentration (Table 9) were obtained by $\mathrm{I}_{2}+\mathrm{K}_{2}-\mathrm{HA}+\mathrm{SS}$ followed by $\mathrm{I}_{2}+\mathrm{SWE}+\mathrm{SS}$ and $\mathrm{I}_{3}+\mathrm{K}_{2}-\mathrm{HA}+\mathrm{RS}$ then $\mathrm{I}_{2}+\mathrm{K}_{2} \mathrm{SiO}_{3}+$ $S S, I_{1}+K_{2}-H A+S S$ and $I_{3}+S W E+R S$ in the two seasons. Also, significant increase in $\mathrm{Ca}$ concentration were induced by $\mathrm{I}_{2}+\mathrm{K}_{2}-\mathrm{HA}+\mathrm{RS}, \mathrm{I}_{3}+$ control (or $\mathrm{K}_{2} \mathrm{SiO}_{3}$ ) $+\mathrm{RS}$ and $\mathrm{I}_{4}+\mathrm{RS}$ plus all drenching applications.

Generally, all drenching applications increased the concentration of the macronutrients under study. Plants were grown on rice straw under $I_{3}$ irrigation and applied with $\mathrm{K}_{2}-\mathrm{HA}$ or SWE showed significant increase in $\mathrm{N}, \mathrm{P}$ and $\mathrm{Ca}$ concentrations, while, under $\mathrm{I}_{4}$ irrigation an increase in $\mathrm{N}$ and $\mathrm{P}$ concentrations was obtained by $\mathrm{K}_{2}-\mathrm{HA}$. While, $\mathrm{K}_{2} \mathrm{SiO}_{3}$ surpassed other treatments with $\mathrm{K}$ concentration under $I_{3} \& I_{4}$. These results confirm with the finding that humic substances enhance the uptake of $\mathrm{K}, \mathrm{Ca}$, magnesium $\mathrm{Mg}$ and $\mathrm{P}$ (Chen and Aviad, 1990). Potassium humate can be used as organic potash fertilizers. It supplies high levels of soluble in readily available forms. Combined with humic acid, potassium, can be rapidly absorbed and incorporated into plant whether via soil or foliar application methods. Enhancement of plant growth using $\mathrm{K}_{2}-\mathrm{HA}$ had been reported to be due to increasing nutrients uptake such as $\mathrm{N}, \mathrm{Ca}, \mathrm{P}, \mathrm{K}, \mathrm{Mg}$, $\mathrm{Fe}, \mathrm{Zn}$ and $\mathrm{Cu}$ (David et al 1994 and Adani et al 1998). Mancuso et al (2006) and Rathore et al (2009) on soybean observed increases in yield as well as $\mathrm{N}, \mathrm{P}$ and $\mathrm{K}$ concentrations with application of SWE. Masny et al (2004) and Attememe (2009) mentioned to the presence of macronutrients in SWE responsible for the improvement of fruit and shoot characters induced by SWE application. Parida and Das (2005) mentioned that selective accumulation of ions is one of the strategies plants develop to cope with abiotic stress and this may explain why the highest concentrations of $\mathrm{k}$ were observed under the highest level of irrigation deficit $\mathrm{I}_{4}$ by $\mathrm{K}_{2} \mathrm{SiO}_{3}$ followed by other drenching applications of plants were grown on SS. With regard that, plants were grown under $\mathrm{I}_{4}$ on SS exposed to higher water stress comparing to those grown on $\mathrm{RS}$ under the same irrigation level. The positive impact of $\mathrm{K}_{2} \mathrm{SiO}_{3}$ on $\mathrm{k}$ concentration is partially attributed to being potash fertilizers.
It could be concluded from the present study that rice straw could alleviate the negative effect of low water supply and applications of $\mathrm{K}_{2}-\mathrm{HA}$ and SWE are recommended for enhancing sweet paper growth and nutrient elements uptake under water deficit conditions.

\section{REFERENCES}

A.O.A.C., 2005. Official Methods of Analysis of AOAC International, Ed 18th. Association of Official Analytical Chemists. Washengton, D.C., USA

Abdel-Maguid, A., El-Sayed, A. and Hassan, H. 2004. Growth enhancement of olive transplants by broken cells of fresh green algae as soil application. Minufiya J. Agric. Res., 29(3), 723-733.

Abdet-Sattar, M., El-Marzoky, H. and Mohamed, A. 2008. Occurrence of soilborne diseases and root knot nematodes in strawberry plants grown on compacted rice straw bales compared with naturally infested soils. J. of Plant Protection Research, 48(2), 223-235.

Abou El-Nasr, M. and Ibrahim, E. 2011. Effect of different potassium fertilizer rates and foliar application with some sources of potassium on growth, yield and quality of carrot plants (Daucus carota L.). Plant Production, Mansoura Univ., 2(4), 559-569.

Adani, F., Genevini, P., Zaccheo, P. and Zocchi, G. 1998. The effect of commercial humic acid on tomato plant growth and mineral nutrition. Journal of Plant nutrition, 21(3), 561-575.

Ahmed, M., Qadeer, U. and Aslam, M.A. 2011. Silicon application and drought tolerance mechanism of sorghum. African J. of Agric. Research, 6(3), 594-607.

Aminifard, M.H., Aroiee, H., Ameri, A. and Fatemi, H. 2012. Effect of plant density and nitrogen fertilizer on growth, yield and fruit quality of sweet pepper (Capsicum annum L.). African J. of Agric. Research, 7(6), 859-866.

Attememe, J. 2009. The effect of humic acid and seaweed extracts on the growth, chemical characteristics Rosmarinus officinalis $L$. In the 6th scientific conference, Biology Dept., College of Education, University of Tikrit. Plant Scie, pp. 1-17.

Awwad, M.S., El-Hedek, K.S., Bayoumi, M.A. and Eid, T.A., 2015. Effect of potassium humate application and irrigation water levels on maize yield, crop water productivity and some soil properties. J. Soil Sci. and Agric. Eng., Mansoura Univ., 6(4), 461 - 482. 
Bank, W. 2006. Directions in Development Reengaging in agricultural water management: challenges, opportunities, and trade-offs. Water for Food Team, Agriculture and Rural Development Department (ARD) World Bank, Washington, DC, $218 \mathrm{p}$.

Bélanger, R.R., Bowen, P.A., Ehret, D.L. and Menzies, J.G. 1995. Soluble Silicon: Its role in crop and disease managementof Greenhouse Crops. Plant Disease, pp. 329-336.

Bosland, P. and Votava, E. 2000. Chemical composition. Peppers: Vegetable and Spice Capsicums.CABI Publishing New York, USA. pp. 84-96.

Chen, Y. and Aviad, T. 1990. Effects of humic substances on plant growth. Humic substances in soil and crop sciences: Selected readings, (humicsubstances), pp. 161-186.

Chernane, H., Latique, S., Mansori, M. and ElKaoua, M. 2015. Salt stress tolerance and antioxidative mechanisms in wheat plants (Triticum durum L.) by seaweed extracts application. J. Agric. Vet Sci., 8(1), 36-44.

Craigie, J.S. 2011. Seaweed extract stimuli in plant science and agriculture. J. of Applied Phycology, 23(3), 371-393.

David, P., Nelson, P. and Sanders, D. 1994. A humic acid improves growth of tomato seedling in solution culture. J. of Plant Nutrition, 17(1), 173-184.

El-Bassiony, A., Fawzy, Z., El-Samad, E.A. and Riad, G. 2010. Growth, yield and fruit quality of sweet pepper plants (Capsicum annuum L.) as affected by potassium fertilization. $\mathbf{J}$. of American Sci., 6(12), 722-729.

El-Sayed, S., Hassan, H. and Mahmoud, S. 2015. Effect of Some Soilless Culture Techniques on Sweet Pepper Growth, Production, Leaves Chemical Contents and Water Consumption under Greenhouse Conditions. Middle East J., 4(4), 682-691.

El-Moniem, E.A.A. and Abd-Allah, A. 2008. Effect of green alga cells extract as foliar spray on vegetative growth, yield and berries quality of superior grapevines, Am. Euras. J. Agric. and Environ. Sci., 4(4), 427-433.

Epstein, E. 1994. The anomaly of silicon in plant biology. Proceedings of the National Academy of Sci., 91(1), 11-17.

Epstein, E. 1999 . Silicon. Annual review of plant biology, 50(1), 641-664.

Epstein, E. 2001. Silicon in plants: Facts vs. Concepts. Studies in Plant Sci., 8, 1-15.
Ezzo, M., Glala, A., Habib, H. and Helaly A. 2010. Response of sweet pepper grown in sandy and clay soil lysimeters to water regimes. American-Eurasian J. of Agric. and Environmental Sci., 8(1), 18-26.

Gomez, K.A. and Gomez, A.A. 1984. Statistical procedures for agricultural research. John Wiley \& Sons.

Horneck, D.A. and Miller, R.O. 1998. Determination of total nitrogen in plant tissue. In Handbook of Referance Methods for Plant Analysis. Kalra, Y.P., ed, pp. 75-83.

Howell, T.A., Tolk, J.A., Schneider, A.D. and Evett, S.R. 1998. Evapotranspiration, yield, and water use efficiency of corn hybrids differing in maturity. Agronomy J., 90(1), 3-9.

Jackson, M. 1973. Estimation of phosphorus content. Soil Chemical Analysis, Prentice Hall, New Delhi , India, pp. 134-182.

Jones, H.G. 2004. What is water use efficiency? In: Water Use Efficiency in Plant Biology (M.A. Bacon). Blackwell Publishing, Oxford, UK, pp. 27-41.

Karakurt, Y., Unlu, H., and Padem, H. 2009. The influence of foliar and soil fertilization of humic acid on yield and quality of pepper. Acta Agriculturae Scandinavica Section B-Soil and Plant Sci., 59(3), 233-237.

Khan, W., Rayirath, U.P., Subramanian, S., Jithesh, M.N., Rayorath, P., Hodges, D.M., Critchley, A.T., Craigie, J.S., Norrie, J. and Prithiviraj, B. 2009. Seaweed extracts as biostimulants of plant growth and development. J. of Plant Growth Regulation, 28(4), 386399.

Kowalski, B., Jäger, A.K. and Van Staden, J. 1999. The effect of a seaweed concentrate on the in vitro growth and acclimatization of potato plantlets. Potato Research, 42(1), 131-139.

Liu, J.J., Lin, S.H., Xu, P.L., Wang, X.J. and Bai, J.G. 2009. Effects of exogenous silicon on the activities of antioxidant enzymes and lipid peroxidation in chilling-stressed cucumber leaves. Agricultural Sciences in China, 8(9), 1075-1086.

Ma, J.F. and Yamaji, N. 2006 . Silicon uptake and accumulation in higher plants. Trends in Plant Sci., 11(8), 392-397.

Mancuso, S., Azzarello, E., Mugnai, S. and Briand, X. 2006. Marine bioactive substances (IPA extract) improve foliar ion uptake and water stress tolerance in potted Vitis vinifera plants. Advances in Horticultural Sci., pp. 156-161. 

plants under irrigation deficit

Marschner, H. 1995. Functions of Mineral Nutrients-8: Macronutrients.

Masny, A., Basak, A. and Zurawicz, E. 2004. Effects of foliar applications of Kelpak SL and Goëmar BM $86 \AA$ preparations on yield and fruit quality in two strawberry cultivars. J. of Fruit and Ornamental Plant Research, 12, 23-27.

Nardi, S., Pizzeghello, D., Muscolo, A. and Vianello, A. 2002. Physiological effects of humic substances on higher plants. Soil Biology and Biochemistry, 34(11), 15271536.

Parida, A.K. and Das, A.B. 2005. Salt tolerance and salinity effects on plants: a Review. Ecotoxicology and Environmental Safety, 60(3), 324-349.

Piorr, H. 1986. Reducing fungicide applications by using sodium silicate and wettable sulphur in cereals. Mededelingen van de Faculteit landbouwwetenschappen - Rijksuniversiteit Gent, 51/2b.

Rafat, N., Yarnia, M. and Hassan Panah, D. 2012. Effect of drought stress and potassium humate application on grain yield-related traits of corn (cv. 604). J. of Food, Agric. \& Environment, 10(2), 580-584.

Rathore, S., Chaudhary, D., Boricha, G., Ghosh, A., Bhatt, B., Zodape, S. and Patolia, J. 2009. Effect of seaweed extract on the growth, yield and nutrient uptake of soybean (Glycine max) under rainfed conditions. South African J. of Botany, 75(2), 351-355.

Refaiy A., EL-Kosary, S., El-Khawaga, A.S. and El-Sherbeny, N.R. 2016. Effect of potassium humate on plant growth and chemical contents of banana plantlets grown in vitro under salinity stress. Middle East J. of Agric. Research, 5(1), 45-49.
Schonfeld, M.A., Johnson, R.C., Carver, B.F. and Mornhinweg, D.W. 1988. Water relations in winter wheat as drought resistance indicators. Crop Sci., 28(3), 526-531.

Sivanesan, I., Son, M.S., Lee, J.P. and Jeong, B.R. 2010. Effects of silicon on growth of Tagetes patula L.'Boy Orange'and 'Yellow Boy'seedlings cultured in an environment controlled chamber. Propag. Ornam. Plants, 10, 136-140.

Spann, T.M. and Little, H.A. 2011. Applications of a commercial extract of the brown seaweed Ascophyllum nodosum increases drought tolerance in container-grown 'Hamlin'sweet orange nursery trees. Hort. Sci., 46(4), 577582.

Wang, T., Jonsdottir, R. and Ólafsdóttir, G. 2009. Total phenolic compounds, radical scavenging and metal chelation of extracts from Icelandic seaweeds. Food Chemistry, 116(1), 240-248.

UNWWAP (United Nations World Water Assessment UN World WaterProgramme), 2003. The $1^{\text {st }}$ Development Report: Water for People, Waterfor Life. Paris, New York and Oxford. United Nations Educational, Scientific and Cultural Organization (UNESCO) and Berghahn Books، 576 p.

Xu, C. and Leskovar, D.I. 2015. Effects of A. nodosum seaweed extracts on spinach growth, physiology and nutrition value under drought stress. Scientia Horticulturae, 183, 39-47.

Zhang, X. and Schmidt, R. 1997. The impact of growth regulators on the $\alpha$-tocopherol status in water-stressed Poa pratensis. Int. Turfgrass Res. J., 8, 1364-1373. 